\title{
Physico-chemical variables and their effect on the growth performance of some major carps in some ponds of a matsaya gram (Fish village) in Natore
}

\author{
Md. Shahadot Hossain and Mohd. Mainul Haque \\ Ecology Laboratory, Department of Zoology, University of Rajshahi, Rajshahi
}

\begin{abstract}
An experiment was carried out to asses the physico-chemical characteristics, water quality and fish growth suffered by pollution hazards created by unethical use of agrochemical in few ponds in a matsaya gram (fish fillage) in northern part of Bangladesh. The range of free $\mathrm{CO}_{2}, \mathrm{DO}, \mathrm{HCO}_{3}, \mathrm{CO}_{3}$ and $p^{\mathrm{H}}$ were 2-30mg/l, 3.14-11.86 mg/l, 86.31-143.84mg/l, $0-50 \mathrm{mg} / \mathrm{l}$ and 8.5-9.5 respectively. The BOD of the studied ponds found quite less than optimum level. The study of relationship between fish growth and the soil characters showed negative impact. It revealed that due to minimum rainfall the ponds were not washed out that could decrease the rate of pollution created from the nearest house and residual chemicals, those used in upland crop field beside it. But the ponds are still suitable for fish culture and should keep them at least in present position for good crop.
\end{abstract}

Key words: Impact, pollutants, pond fisheries, matsaya gram.

\section{Introduction}

It is well recognized that the water quality plays an important role on fish production. A pond with good water quality will produce more healthy fish than a pond with poor water quality. So, the production of fish in any water body depends largely on the availability of food organisms of the water body. The role of water pollutants has a direct affect on fish health. Several environmental factors, which determine the character of water, have great importance upon the growth, maturity, reproduction and development of fishes. The relationship between fishes and their biotic and abiotic factors is not an isolated phenomenon, but change in one may reflect on the other effectively. Fishes are more dependent on water temperature, $\mathrm{pH}$, dissolved oxygen, free $\mathrm{CO}_{2}$, alkalinity and some other salts for growth and development (Nikolsky, 1963).

Since the last few years due to natural and man made causes biodiversity especially species diversity of fishes and other aquatic organisms in open water have been decreasing drastically. This situation is creating a lot of problem for human and as well as organisms of aquatic environment.

The importance of the assessment of limnological factors is of great importance. Soil quality and water quality study are also important. The study helps to formulate the guideline for management of fish culture practices. The limnological factors on hydrology deal with many interested phenomena, such as, hydrophytes phytoplankton, zooplankton to benthic fauna, fish diversity, physical and chemical nature of water body
(Banerjea, 1967). Fishes are more dependent on water temperature, $p \mathrm{H}, \mathrm{DO}$, free carbon dioxide, alkalinity, hardness and some salts for growth and development (Nikolsky, 1963). Any change of these parameters may affect the growth, development and maturity of fishes. (Nikolsky, 1963). In short, water quality is directly related to productivity of fish and determines the quality of their lives.

Considering the importance of pond fishery to the economy and to human health, this study was conducted on few selected ponds in a matshya village. The study has been conducted to asses the water quality of the ponds and their impacts on pond fishes.

\section{Materials and Methods}

The physico-chemical study was started from October 2008 to March 2010. The water sample, for test was collected from 10 ponds in matsaya villages of Baraigram upazilla, Natore. Sampling and physical test was done weekly on all the 10 ponds. The methods used to test different parameters are described below:

Turbidity: Turbidity was measured by Seechi disc. The disc was slowly lowered in the water and the depth at which the disc becomes invisible was noted from the scale reading. The turbidity was then calculated from turbidity chart. Turbidity of water is expressed in $\mathrm{mg} / \mathrm{l}$.

$\mathbf{p H}$ (Potenz Hydrogen) ${ }^{\prime} \mathrm{pH}$ refers to the amount of hydrogen ions in a solution. $\mathrm{P}^{\mathrm{H}}$ of pond water was measured by a digital $p \mathrm{H}$ meter (HANNA model $\mathrm{HI}$ 96107) made in Italy. The $p \mathrm{H}$ was measured directly by immerging the meter knod into the water. 
Temperature: The temperature of water was measured at the time of sample collection by an alcoholic centigrade thermometer with the range $0^{\circ} \mathrm{C}$ to $110^{\circ} \mathrm{C}$. The thermometer was immerged directly into the water and the reading was noted.

Dissolved oxygen: The dissolved (DO) oxygen concentrations of the collected samples were determined immediately by titration method following the Winkler's method (APHA 1976). DO was measured weekly.

Free carbon-dioxide: Free carbon-dioxide $\left(\mathrm{CO}_{2}\right)$ in the water was determined by the method of titration of sample with $\mathrm{N} / 44 \mathrm{NaOH}$ solution using phenolphthalein as an indicator (Welch, 1948). The test was done immediately after collecting the water sample. Samples were collected from the pond four times in a month.

Carbonate: Carbonate $\left(\mathrm{CO}_{3}\right)$ alkalinity was determined by titration of $100 \mathrm{ml}$ of water sample with $\mathrm{N} / 50$ sulfuric acid using phenolphthalein as indicator (Welch, 1948). This test was completed within thirty minute of sample collected.

Bicarbonate alkalinity: Bicarbonate $\left(\mathrm{HCO}_{3}\right)$ alkalinity was determined by titration of $100 \mathrm{ml}$. of water sample with N/50 sulfuric acid using methyl orange as an indicator (Welch, 1948).

Biological oxygen demand : For the measurement of biological oxygen demand (BOD) Two bottles each of $250 \mathrm{ml}$ capacity were taken and then the bottles were filled with water from the pond as sample. The dissolved oxygen in one bottle was determined immediately by using the DO measurement method. But the other bottle was incubated at $20^{\circ} \mathrm{C}$ for 5 days. After 5 days, the DO was measured by the same method as described above. The value of BOD was determined by subtracting final dissolved oxygen (DO) from initial dissolved oxygen.
Fish collection: The weight of fishes were taken after every three months. During harvest rui, mrigel, catla, silver carp, and mirror carp fishes were taken as sample and weight was taken near the pond site.

\section{Results and Discussion}

Quarterly average turbidity, $p \mathrm{H}$ and water temperature of the studied ponds are presented in Table 1 and dissolved $\mathrm{O}_{2}, \mathrm{CO}_{2}, \mathrm{CO}_{3}$ and $\mathrm{HCO}_{3}$ concentration in the water is presented in Table 2. The water remained more turbid in the $1^{\text {st }}$ quarter of 2010. The DO and bi-carbonate also remained the higher during that quarter. The $\mathrm{pH}$ amount did not differ much. But the concentration of $\mathrm{CO}_{2}$ and $\mathrm{CO}_{3}$ observed higher in the $3^{\text {rd }}$ quarter of 2009. The measured BOD $(\mathrm{mg} / \mathrm{l})$ in the water of those ponds is presented in Table 2.

Table 3. Biological oxygen demand (BOD) of ten ponds tested quarterly.

\begin{tabular}{|c|c|c|c|c|c|c|}
\hline \multirow[b]{2}{*}{$\begin{array}{l}\text { Pon } \\
\text { d no. }\end{array}$} & \multicolumn{6}{|c|}{ Biological oxygen demand (BOD mg/ I) } \\
\hline & $\begin{array}{c}\text { 4th } \\
\text { quart } \\
\text { er } \\
2008\end{array}$ & $\begin{array}{c}\text { 1st } \\
\text { quart } \\
\text { er } \\
2009\end{array}$ & $\begin{array}{c}\text { 2nd } \\
\text { quart } \\
\text { er } \\
2009\end{array}$ & $\begin{array}{c}\text { 3rd } \\
\text { quar } \\
\text { er } \\
2009\end{array}$ & $\begin{array}{c}\text { 4th } \\
\text { quart } \\
\text { er } \\
2009\end{array}$ & $\begin{array}{c}1 \mathrm{st}^{\mathrm{t}} \\
\text { quart } \\
\text { er } \\
2010\end{array}$ \\
\hline 1 & 6.28 & 4.19 & 3.49 & 2.64 & 6.28 & 5.24 \\
\hline 2 & 7.14 & 2.40 & 2.79 & 1.70 & 5.59 & 1.40 \\
\hline 3 & 6.25 & 2.79 & 2.09 & 1.31 & 5.59 & 2.66 \\
\hline 4 & 5.32 & 2.80 & 3.49 & 2.17 & 0.69 & 3.84 \\
\hline 5 & 2.12 & 3.49 & 2.55 & 2.07 & 1.40 & 4.40 \\
\hline 6 & 1.32 & 3.49 & 3.32 & 2.44 & 1.47 & 4.19 \\
\hline 7 & 5.42 & 2.09 & 3.50 & 2.78 & 6.29 & 3.15 \\
\hline 8 & 5.70 & 2.09 & 2.97 & 2.29 & 4.19 & 0.70 \\
\hline 9 & 4.12 & 2.10 & 3.02 & 2.10 & 2.09 & 3.01 \\
\hline 10 & 2.62 & 2.79 & 2.56 & 3.01 & 2.79 & 4.19 \\
\hline $\begin{array}{l}\text { Mea } \\
n\end{array}$ & 4.63 & 2.82 & 2.98 & 2.25 & 3.64 & 3.28 \\
\hline
\end{tabular}

The higher mean of biological oxygen demand (BOD) was recorded in the 4th quarter of 2008 (Table 3 ). The values were analyzed by analysis of variance.

Table 4: Quarterly growth and total weight (in g) of different fishes in 10 ponds.

\begin{tabular}{|c|c|c|c|c|c|c|c|c|c|c|}
\hline \multirow{3}{*}{ Pond } & \multicolumn{10}{|c|}{ Weight of fishes in $\mathrm{g}$} \\
\hline & \multicolumn{2}{|c|}{ Silver carp } & \multicolumn{2}{|c|}{ Rui } & \multicolumn{2}{|c|}{ Catla } & \multicolumn{2}{|c|}{ Mrigel } & \multicolumn{2}{|c|}{ Mirror carp } \\
\hline & quarterly & Total & quarterly & Total & quarterly & Total & quarterly & Total. & quarterly & Total. \\
\hline 1 & 320 & 1800 & 285.00 & 1710 & 288.33 & 1730 & 193.33 & 1160 & 301.66 & 1810 \\
\hline 2 & 400 & 2400 & 316.66 & 1900 & 345.83 & 2075 & 226.66 & 1360 & 534.16 & 3225 \\
\hline 3 & 583 & 3500 & 346.66 & 2150 & 510.00 & 2060 & 400.00 & 2400 & 783.33 & 4700 \\
\hline 4 & 235 & 1415 & 163.33 & 980 & 160.00 & 960 & 122.50 & 735 & 500.00 & 3000 \\
\hline 5 & 312 & 1870 & 308.33 & 1850 & 475.00 & 2850 & 163.33 & 980 & 600.00 & 3600 \\
\hline 6 & 397 & 2380 & 283.33 & 1700 & 245.83 & 1475 & 303.33 & 1820 & 428.33 & 2570 \\
\hline 7 & 374 & 2245 & 300.00 & 1800 & 272.50 & 1635 & 256.66 & 1540 & 419.66 & 2950 \\
\hline 8 & 610 & 3660 & 328.33 & 1970 & 260.00 & 1560 & 341.66 & 2250 & 795.83 & 4775 \\
\hline 9 & 513 & 3075 & 225.00 & 1350 & 204.16 & 1225 & 275.00 & 1650 & 808.33 & 4850 \\
\hline 10 & 478 & 2870 & 327.50 & 965 & 230.50 & 1385 & 230.83 & 1535 & 876.66 & 5260 \\
\hline Mean & 422.2 & 2521.5 & 288.41 & 1637.5 & 299.22 & 1695.5 & 251.33 & 1543 & 604.80 & 3674 \\
\hline
\end{tabular}


Quarterly (during 3 months) growth and total weight of different fishes (after 18 months) in 10 ponds are presented in Table 4. The growth rate of catla and mrigel are comparatively lower than other fishes observed in every pond. Mirror carp grow very rapidly and the average weight become $3600 \mathrm{~g}$ after 18 months.

The relationship between the fish growth and different physical and chemical factor of waters of different ponds were studied and (coefficient correlation) $r$ values were calculated. Turbidity showed direct relation with the growth of silver carp, rui and catla. BOD of water has inverse relation with fish growth.

During the present study different physicochemical variable in 10 ponds and growth of fishes upto 18 months were studied. The growth of some carps (biota) was also taken into consideration. The productivity of an aquatic ecosystem is governed by the physical, chemical and biological characteristics of the ecosystem. The overall behaviour and nature of an environment is largely governed by the interaction of the meteorological, physical, chemical and biological parameters, but a factor is not always independent. There remains a close relationship among the factors. A little variation in one of the factors may influence the other. Similar type of interaction was observed in the present study.

Temperature is one of the most outstanding and biologically significant phenomenona of aquatic environment. All metabolic and physiological activities and life processes such as feeding, reproduction, movement and distribution of aquatic organisms are greatly influenced by water temperature. Bhuiyan and Nessa (1996) observed limited degree of positive relationship between water temperature and water turbidity. They observed positive relationship betweemn $\mathrm{pH}$ and water temperature $(r=0.09)$ and inverse relationship with free $\mathrm{CO}_{2}(\mathrm{r}=-0.66)$ and alkalinity $(\mathrm{r}=-0.87)$. Temperature tolerance limits for Indian major carps and common carps is reported to be $18.3^{\circ} \mathrm{C}$ and $37.8^{\circ} \mathrm{C}$. The temperature recorded from the studied ponds was within the acceptable limit for the species cultured.

The concentration of free carbon-dioxide was found to be directly related to the amount and nature of biological activity in the water. In the present study the high free $\mathrm{CO}_{2}$ content during spring months was possibly due to low temperature and low rainfall. Which caused low decomposition of organic matter and addition of free $\mathrm{CO}_{2}$ high photosynthesis which consumed high precipitation of free $\mathrm{CO}_{2}$ agreeing with Michael (1968) in India and Patra and Azadi (1987) in Bangladesh.

The low temperature and low rainfall results the lower decomposition of organic matter causing lower production of free $\mathrm{CO}_{2}$ and lower consumption of dissolved oxygen Patra and Azadi, 1987).

Michael (1968). found that the bicarbonate alkalinity of pond water ranging from 86.31 to $143.84 \mathrm{mg} / \mathrm{l}$ is suitable for fish cultivation. The alkalinity above $40 \mathrm{mg} / \mathrm{l}$ is considered to be hard water characteristic, which help to maintain the $p \mathrm{H}$ value in alkaline condition. Bicarbonate constitutes the chief source of alkalinity at a $\mathrm{pH}$ range of 7.00 to 9.00. It may also be assumed that in pond the main source of alkalinity may be due to a high content of bicarbonate. Yaron (1964) observed that the alkalinity of an aquatic habitat partly depends on the amount of water in it.

In most water bodies bicarbonate and carbonate are the predominant bases that contribute to the alkalinity. The alkalinity of water is considered one of the most important aspects of the chemistry of water to be used in aquaculture ponds (Boyd 2000). During the study period its higher values were observed in the winter season whereas the lower values were observed in the others season. The observed $\mathrm{pH}$ value of ponds water showed to be alkaline in nature with small variation.

The BOD is the quantity of oxygen in $\mathrm{mg} / \mathrm{l}$ used in oxidatoin in water. BOD represent the concentration of organic matter remaining in the water at any time and DO shows the ability of the water body to purity itself through biochemical. According to Khanna (1992), BOD may be measured at a rate of removal of oxygen from natural water by microorganisms in aerobic degradation of the dissolved or even particulate organic matter in winter. Palharya et al. (1993) noticed that seasonal variation in the value of $B O D$ appears to be a function of changes in the degree of dilution, quantity of organic matters and activities of microorganisms carrying out decomposition of carbonaeous and nitrogenous matter. The highest value of BOD indicated very high degree of organic pollution. In the present study the recorded highest value $4.29 \mathrm{mg} / \mathrm{l}$ is alarming. As BOD is a good measure of the contamination level of a water and it is used primarily for waters that receive pollution from sewage and industrial waters it should be within range for better aquaculture. The result 
obtained from this study suggest the alarming situation of the ponds. The water characters are somewhat beyond the range and these conditions are caused due to over household use that contaminating the water particularly in the winter season when water reserve / containing become very low. It is also observed from this study that the heavy rainfall normalize the all conditions and washed away the pollutants developing the water quality in many cases.

\section{References}

APHA. 1976. Standard methods for the examination of water and waster $\left(4^{\text {th }}\right.$ ed). American Public Health Association, Washington. $1193 \mathrm{pp}$.

Banerjea, S. M.; 1967. Water quality and soil condition of fish ponds in some ststes of Indian in relation to fish production.Ind.j.Fish,14, 115-144

Bhuiyan, A. S. and Nessa, Q. 1996. Study on the physico chemical parameters of a fish pond. Bangladesh . J. biosci. 4: 171-173.

Boyd, C.E. 2000. Water quality, an introduction. .Kluwer Academic Publishers. Boston, Massachusetts. 330 pp.
Khanna, D.R, Badola, S.P. and Rawat, H. S. 1992. Limnology of Dhella river. In Aquatic Environment (ed.A .Gautum).m, Ashish Publication H ouse. New Delhi. 144 pp.

Michael , R.G. 1968. Studies on the zooplankton of a tropical fish pond. Hydrobioogy 32: 47-68.

Nikolsky, G. V.1963. Special Ichthyology (Trusted from Russian By J.I. Lengy and Z.Kranthamer) Jerusalem, Israel programme for Scientific Translation Ltd. PST-Cat 223. $538 \mathrm{pp}$.

Patra, R. W. R. and Azadi, M. A.1987. Ecological studies on the planktonic organisms of the Halda River. Bangladesh J. Zool. 15(2): 109-123.

Palharya, J. P. Siriah, V. K. and Malviya.1993 .Environmental Impact of Sewage and Effluents Disposal on the River System. Ashish Publishing House. Punjab Bagh, New Delhi.: 179 pp.

Welch, P. S. 1948. Limnology methods. Mc graw- Hill Book Company. Inc., New York. 381 pp.

Yaroon, Z. 1964. Notes on the ecology and Entromostracan fauna of temporary rainfall in Israel. Hydrobiol. 3-4: 489513. 